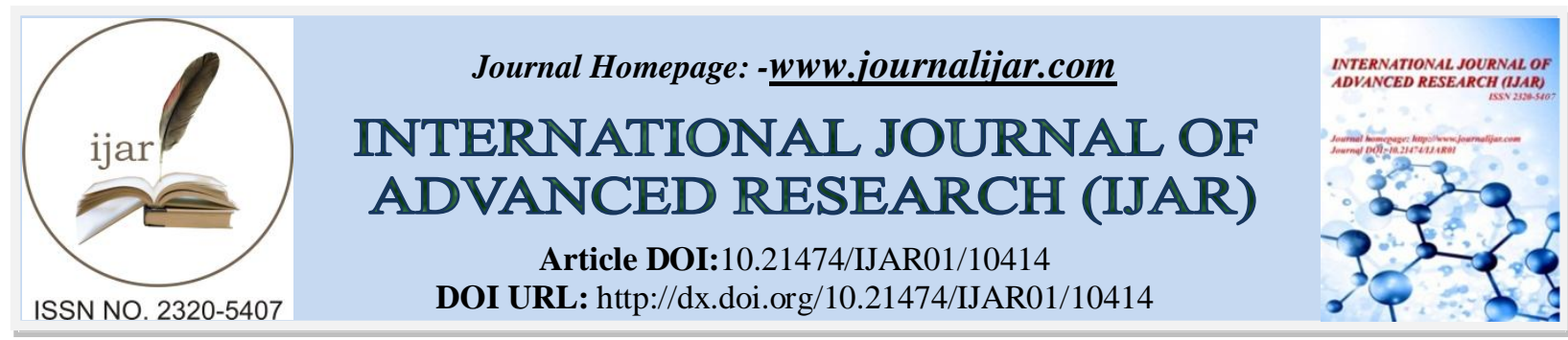

RESEARCH ARTICLE

\title{
PUBLIC HEALTH EFFECT OF HEAVY METALS POLLUTION ON SOME BIOCHEMICAL PARAMETERS IN DOMESTIC BIRDS: CAMP2 VILLAGE IN AKAMKPA LOCAL GOVERNMENT AREA OF CROSS RIVER STATE
}

Eteng Ofem E ${ }^{1}$, Joe, Enobong ${ }^{2}$, Victor Ekam, Savour Ufot $^{2}$, Iwara Arikpo ${ }^{2}$ and Eyong Ubana ${ }^{2}$ 1. Department of Biochemistry, Federal University of Agriculture, Abeokuta, Ogun State

2. Department of Biochemistry, University of Calabar, Cross River State.

\section{Manuscript Info}

Manuscript History

Received: 30 November 2019

Final Accepted: 31 December 2019

Published: January 2020

\section{Key words:-}

Nickel, Cadmium, Lead, Arsenic, Mercury, Chromium, Atomic Absorption Spectrophotometer

\section{Abstract}

The Present study was carried out to assess the heavy metals concentration on domestic birds consumed in Camp2 Community of Akamkpa local government area of Cross river state (Nigeria). A total of twelve (12) local domestic birds (males) (6 from Camp2 and 6 from Ugep respectively) which were sexually mature (between 10-12 months of age) with normal feather, were obtained from local farmers, the blood samples were collected through the wing feather. Heavy metals analysis was carried out using atomic absorption spectrophotometer (AAS) after a wet digestion. Heavy metals such as Cadmium (Cd), Lead $(\mathrm{Pb})$, Mercury $(\mathrm{Hg})$, and Chromium (Cr), Arsenic (As), Nickel (Ni) in domestic birds' samples were determined. The results show that there was a significant increase in heavy metals concentration in Camp2 village compared to the control site. Hence, $\mathrm{Ni}, \mathrm{Pb}$, and $\mathrm{Cd}$ were found in higher levels more than the maximum limit recorded above. Also, the activities of serum alanine transaminase (ALT), aspartate transaminase (AST) and alkaline phosphatase (ALP) shows significant increase $(\mathrm{p}<0.05)$ in Camp2 birds compared to the control site. The concentrations of the electrolytes such as $\mathrm{Na}, \mathrm{K}, \mathrm{Cl}$, Creatine, bicarbonate and bilirubin were significantly higher across the two study sites. There was also a significant increase in serum lipid concentration of domestic birds in the control site compared to the study site in camp2 village.

Conclusion: The result could lead to the modification of the synthetic integrity of the cells, and alteration membrane permeability leading to hepatocellular damage. Thus, it might also be as result of bioaccumulation due to long-term exposure to environmental contaminants. The report further suggests that the toxicological effect of heavy metals in the domestic birds could bring about negative impact in human health after a long time of consumption.

Copy Right, IJAR, 2020,. All rights reserved.

\section{Introduction:-}

The advancement of a country is more often assessed in terms of its technological know-how and acquisition, mostly in relation to machinery and power-operated or producing equipment. Because every country is anxious to be 
identified as developed or progressive, the tendency is to acquire the technology first and then worry later about its consequences, especially consequences to the environment (Chalatte, 1979). Quarrying activity is a necessity that provides much of the materials used in traditional hand flooring, such as granite, limestone, marble, sand stone, slate and even man-made activities (anthropogenic factors). Quarrying activities has a significant impact on the environment (Olorunfemi, 2009). In particular, it is often necessary to blast for processing but this method of extraction results in biodiversity and habitat destruction. Heavy metal pollution of the environment, even at low levels and their resulting long-term cumulative health effects are among the leading health concern all over the world (Oluyemi, 2008). Open quarries are sources of various environmental and health hazards. The decomposition of organic materials produces methane, which may cause explosion and produce leachate, which pollute surface and ground water (Cointrea, 1997). Heavy metal from quarries can accumulate and persist in soils at an environmentally hazardous level (Alloway, 1996). This constitutes serious health and environmental concerns because of phytotoxicity of these metals to the plants and the potential health implications to humans and animals consuming vegetables (Pillay, 2003). Studies have shown that quarry dust may increase heavy metal concentration in soil and underground water (Abores, 2000). Thus, the environmental impact on quarry communities are greatly influenced by their heavy metal contents.In the last three decades they have been an increase in global concern over the public health impacts attributed to environmental pollution, in particular, the global burden of disease (UNDP, 2006). Most of these environmental related diseases are however, not easily detected and may be acquired during childhood and manifested later in adulthood (Kimanic, 2007). The land owners have been advised on methods that can reclaim the land, outside using the land as quarry site. They rather can move a far distance for their agricultural activities. However, this is not the cause as a result of hardships by the land owners. They use the site for farming while water from the nearby quarry site is used for irrigation or domestic purposes without regard to the risk of toxic metal pollution by the quarry sites. The extent to which this has been the case for the people of Akamkpa quarry community is not known. It is based on this understanding therefore that this study was undertaken. The study attempted to address part of this problem by assessing the levels of heavy metals in domestic birds. Quarry sites are a growing concern in Akamkpa communities, as their impact on the ecosystem contribute to the degradation of the environment and pose a health hazard to the surrounding populations at large. Most affected are those living around the quarry sites due to the potentials of the waste to pollute water, food sources, land, air and vegetation (UNHabitat, 2008). Akamkpa communities are exposed to a lot of environmental and health conditions (Affullo, 2009). Some of the problems result from the current inability of urban authorities to adequately manage the quarry site. This has resulted in uncontrolled and unmonitored waste in the communities, with the consequences of contamination and subsequent pollution of the environment by heavy metals. Heavy metals have become a source of global concern due to their widespread distribution and multiple effects on the ecosystem (Uwah, 2011). Most of the waste comprise organic materials, considerable proportions of particles which are known to be real sources of heavy metal (Lisk, 1998). Furthermore, heavy metals are non-biodegradable and can accumulate in soils to toxic concentrations that affect plant and animal (Karatas, 2006). Trace metals may enter the human body via consumption of contaminated water or crops grown on contaminated land (Dudka, 1999). Metals such as lead, mercury, cadmium and copper are cumulative poisons which cause environmental hazards and are reported to be exceptionally toxic. These metals are a major source of oxidative stress in cells and play an important role in the etiology of diverse human pathologies such as carcinogenesis (Frenkel, 1992). Exposure to heavy metal toxicity leads to brain damage, mental retardation, cerebral palsy, lung cancer, gastrointestinal abnormalities, dermatitis and death of the unborn foetus, (USEPA, 2002). Many metals have been shown to directly modify or damage DNA by forming DNA adducts that induce chromosomal breaks (Chakarabarti, 2001). The quarry sites where all these activities take place and raw materials, much of which eventually finds its way back to the neighborhoods as animal's feed. Stray chicken, pigs, goats, dogs and cats roam within the affected land eating the toxic matter and becoming vectors of pests and parasites that eventually transfer to surrounding homes, causing diseases to both animals and humans.

\section{Materials Methods:-}

\section{Equipment and instruments:}

Atomic Absorption Spectrophotometer (model SOLAAR 969AA Schemduu Company, Japan. Centrifuge (802 electric table centrifuges from B-Bran Scientific Instrument Company, England), semi-auto Biochemistry Analyzer (Model Aj-1222 from Easy way medical Equipment Ltd., England), Spectrophotometer analyzer (Model Bc2600Kx-21N, from mid-Ray Ltd, England, water bath (Searl Instruments, Satchwell, Sunvic Ltd, England). 


\section{Reagents/chemicals used:}

All the reagents and chemicals used were of analytical grades and they include the following: coded International Atomic Energy Agency (IAEA-336) from Sigma, USA Nitric acid (Riedel Haen Germany), perchloric acid (SigmaAldrich, Germany), Distilled deionized water obtained from Central Analytical Laboratory Institute of Oceanography University of Calabar. All Biochemical assays were carried out using Agape Kit and Aj-semi-auto Biochemistry Analyzer.

\section{Study location:-}

The study area is located in the Southern Senatorial District of Cross River State within latitude $5^{0} 24^{1} \mathrm{~N}$ and longitude $8^{0} 12^{1} \mathrm{E}$. The topography of the area is strongly undulating while the vegetation is typically rainforest which is gradually detoriating via quarry activities. The Camp2 in Mfamosing village is located at Akamkpa Local Government Area of Cross River State. It is 36 kilometers from Calabar, the capital city of Cross River State. The community is located close to the quarry site of Mfamosing rich in industrial activities. The control site for the same study is located at Ugep in Central Senatorial District of Cross River State within the latitude $5^{0} 48^{1} \mathrm{~N}$ and longitude $8^{0} 5^{1} \mathrm{E}$. It is 122 kilometers from Calabar. The village is populated by the Yakurr people. Ugep is believed to be the largest village in Africa by land mass (Obono, 2004). The National Demographic Survey (2008) also added that the population is indeed predominantly Christian. The predominant occupation of the people of Camp2 and Ugep is farming with over $70 \%$ of its people being engaged in various forms of agriculture. The major agricultural produce includes cassava, yam, vegetables, rice, plantain etc. The high yielding quarry operations and tourism potentials of the people of Akamkpa has placed the state in vintage economic position and stability. Hence, the local government is blessed with natural resources that could promote economic growth in the state.

\section{Field work:-}

Sampling points were chosen in order to assess the characteristic features, About Twelve Domestic birds six (6) each were used in the two study areas in Ugep and Camp2 Akamkpa Local Government Area. This was to enable the investigation of potential source of pollution and establish the impact of the emission of industrial waste from the quarry site to the study community

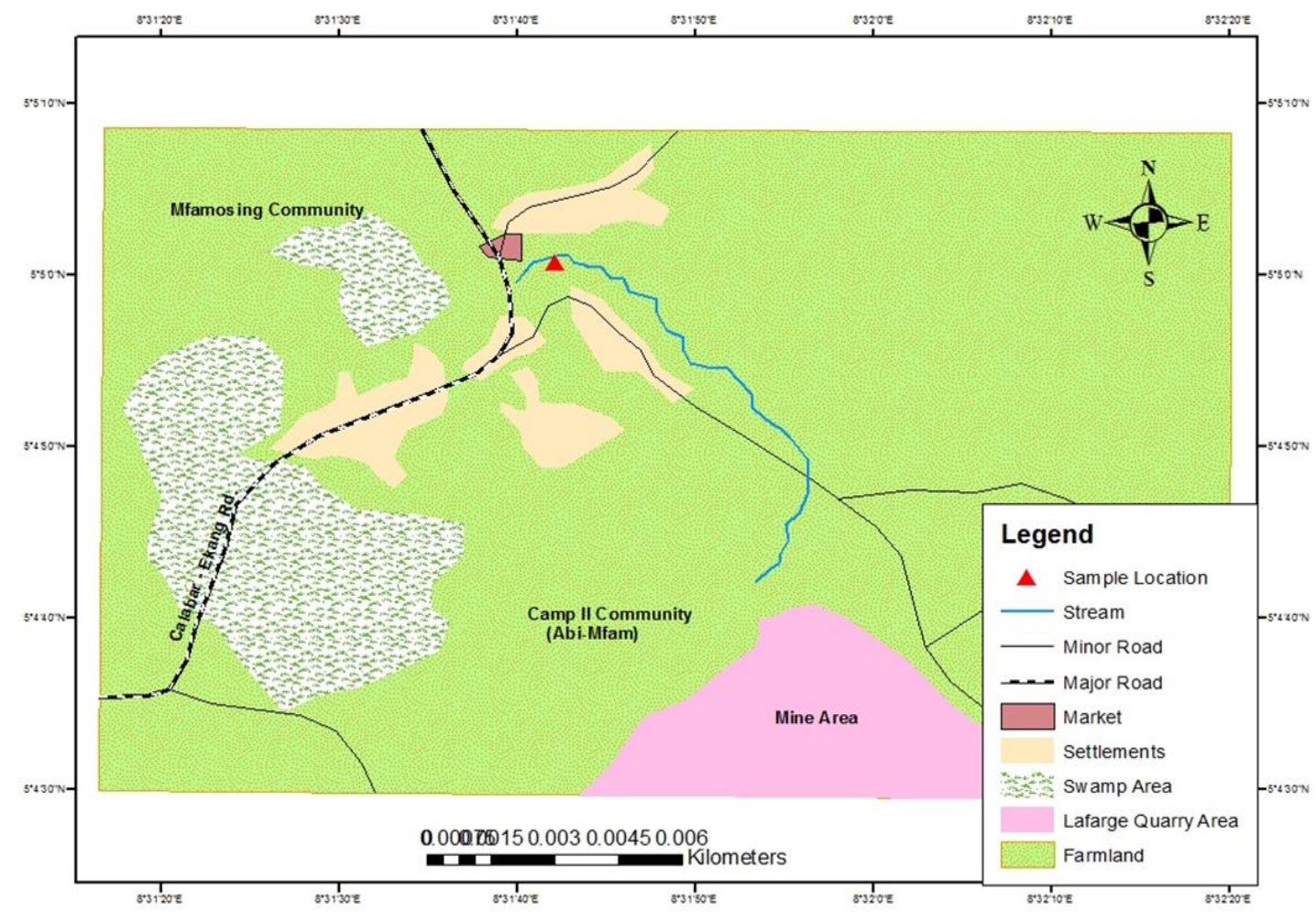

FIG. 1:- Map of camp2 showing the features of the quarry site. 
FIG. 2:- Map of the Control Site

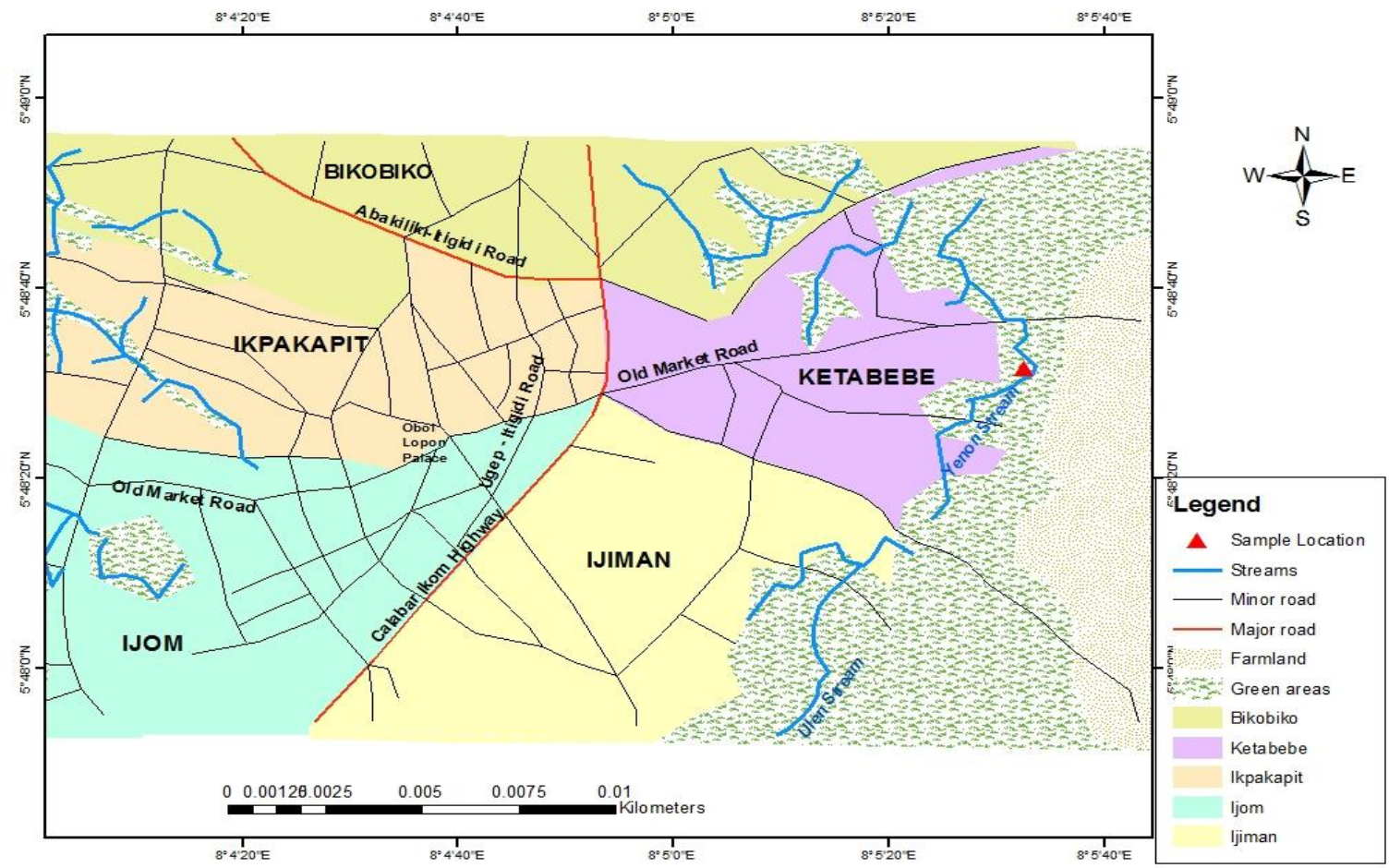

Source: Geographic Information System (GIS) Laboratory, Department of Geography and Environmental Science, University of Calabar

\section{Relief, drainage and topography:}

The Areas were well drained with streams and most of the streams contain water bodies which are used by the surrounding communities extensively for drinking and agricultural purposes. Also, the area consists of two land types which are mountainous area, and is about $250 \mathrm{~m}$ in height above sea level. Hence the area has a geological formation.

\section{Climate:}

The study area is part of the wet climate zone of Cross River State. It is also characterized by an annual rainfall occurring within the month of May, June, July, October and November.

\section{Animal protocols:}

A total of twelve (12) local domestic birds (males) (6 from Camp2 and 6 from Ugep respectively) which were sexually mature (between 10-12 months of age) with normal feather, were obtained from local farmers in the control site and Camp2 village, both of Cross River State, were used for the study.

\section{Blood sample collection:}

The blood samples were collected from the wing veins of the birds using $2 \mathrm{ml}$ disposable syringes and a portion directly transferred into a labeled bottle containing EDTA (Ethylenediaminetetraacetic acid anti-coagulant) while the remaining portion blood was allowed to clot. The non-coagulated blood was used to determine the biochemical indices. Afterwards the same quantity of the blood was subjected to centrifugation at 300rp for 15 mints, to get the blood serum samples that were used to measure toxicological indices using $5 \mathrm{ml}$ syringe and needle.

\section{Samples preparation:}

The samples were digested according to standard methods for the investigation of blood, American (APHA, 2005). The samples were thoroughly mixed, $5 \mathrm{ml}$ of the blood serum was transferred into a conical flask, $25 \mathrm{ml}$ conc. nitric acid and $5 \mathrm{ml}$ of perchloric acid was added and brought to slow boiling on an evaporating plate to lowest volume (25mI). Nitric acid was added, as necessary. Digestion was completed as shown by light colour and a clear solution. 
The solution was not allowed to get dried during digestion. The digest was filtered into 50ml volumetric flask diluted with distilled water. for elemental analysis with Atomic Absorption Spectrophotometer (SOLAAR, 969 AA).

\section{Ethical consideration:}

Approval for this research work was granted by the ethical committee, Faculty of Basic Medical Sciences, University of Calabar.

\section{Data analysis:}

Data obtained was expressed as Mean \pm Standard Deviation and was analysed using the student's t-test where applicable. Mean values $\mathrm{p}<0.05$ were regarded as significant in comparison to appropriate controls. While statistical analysis was also carried out using predictive analytic software for window (SPSS package 19.0). Values at $\mathrm{p}<0.05$ was regarded as significant in comparison with appropriate controls.

\section{Results:-}

Comparison of serum enzymes and bilirubin concentration in domestic birds (Gallus domestica) in Camp2 and control site:

The serum activities of Aspartate amino transferase (AST) alanine aminotransferase (ALT) and alkaline phosphatase (ALP) are presented in Table 9 which also indicates total bilirubin (TB), conjugated bilirubin (CB) and unconjugated bilirubin. The mean value of AST activities was significantly higher $(\mathrm{P}<0.05)$ at Camp2 with a mean value of $42.60+2.25 \mathrm{IU} / \mathrm{L}$ compared with the control site value of $25.60+1.81 \mathrm{IU} / \mathrm{L}$. The mean value of ALT was significantly higher at $(\mathrm{P}<0.05)$ in Camp2 with a mean value of the $40.40+1.25 \mathrm{IU} / \mathrm{L}$ compared to the control site with a mean value of $25.00+2.41 \mathrm{IU} / \mathrm{L}$. Also, there was a significant increase in ALP at Camp2 with a mean value of 103.08+4.59IU/L compared to the control site with a mean value of $61.12+5.73 \mathrm{IU} / \mathrm{L}$. However, there was also a significant increase in total bilirubin in Camp2 $(\mathrm{P}<0.05)$ with a mean value of $19.32+0.53 \mathrm{mg} / \mathrm{dL}$ compared to the total bilirubin at the control site with a mean value of $12.26+0.90 \mathrm{mg} / \mathrm{dL}$. The activities of AST, ALT and ALP in Camp2 birds were significantly higher than those of control birds $(p<0.05)$. Similarly, the concentrations of all forms of bilirubin (total, conjugated and unconjugated) were significantly higher $(\mathrm{p}<0.05)$ than those of control.

Table 1:-Activities of serum enzymes and bilirubin concentrations in domestic birds (Gallus domestica).

\begin{tabular}{|l|l|l|l|l|l|l|}
\hline & AST(IU/L) & ALT(IU/L) & ALP(IU/L) & TB(mg/dL) & CB(mg/dL) & UB $(\mathrm{mg} / \mathrm{dL})$ \\
\hline Camp2 & $42.60 \pm 2.25$ & $40.40 \pm 1.25$ & $103.08 \pm 4.59$ & $19.32 \pm 0.53$ & $8.96 \pm 0.35$ & $10.36 \pm 0.72$ \\
\hline Control site & $25.60 \pm 1.81^{*}$ & $25.00 \pm 2.41^{*}$ & $61.12 \pm 5.73^{*}$ & $12.26 \pm 0.90^{*}$ & $4.84 \pm 0.35^{*}$ & $7.42 \pm 0.64^{*}$ \\
\hline
\end{tabular}

Values are expressed as mean \pm SEM, $\mathrm{n}=6$

$*$ significantly different from CAMP2 at $\mathrm{p}<0.05$

AST - Aspartate aminotransferase

ALT - Alanine aminotransferase

ALP - Alkaline phosphatase

TB - Total bilirubin

CB - Conjugated bilirubin

UB - Unconjugated bilirubin

Comparison of serum lipid concentration in domestic birds (Gallus domestica) in Camp2 and control site:

The serum lipid parameters of domestic birds were analyzed for total cholesterol, high density lipoprotein (HDL), low density lipoprotein (LDL), very low-density lipoprotein (VLDL) and triacylglycerol (TG). Results are presented in (Table10) below. The total cholesterol (TC) were significantly higher $(p<0.05)$ at the control site $(4.41+0.34 \mathrm{mg} / \mathrm{dL})$ when compared with total cholesterol (TC) in Camp2 $(3.30+0.19 \mathrm{mg} / \mathrm{dL})$. The mean value of high-density lipoprotein (HDL) also show a significant increase $(\mathrm{P}<0.05)$ at the control site with a mean value of $1.12+0.07$ compared to the high-density lipoprotein in Camp2 with a mean value of $0.66+0.13$. Also, there was a slight increase $(\mathrm{p}<0.05)$ of low-density lipoprotein (LDL) at the control site with a mean value of $2.80+0.14 \mathrm{mg} / \mathrm{dL}$ compared to the low-density lipoprotein (LDL) at Camp2 with a mean value of $2.28+0.12 \mathrm{mg} / \mathrm{dL}$. There was also a slight increase $(\mathrm{p}<0.05)$ in $(\mathrm{VLDL})$ very low-density lipoprotein at the control site with a mean value of $0.48+0.02 \mathrm{mg} / \mathrm{dL}$ compared to Camp2 with a mean value of $0.38+0.02 \mathrm{mg} / \mathrm{dL}$. The was also a significant increase in TG level $(\mathrm{p}<0.05)$ at the control site with a mean value of $1.04+0.05 \mathrm{mg} / \mathrm{dL}$ compared to the TG level at the study site Camp2 with a mean value of $(0.60+0.06 \mathrm{mg} / \mathrm{dL})$. 
Table 2:- Comparison of serum lipid concentrations in domestic birds (Gallus domestica).

\begin{tabular}{|l|l|l|l|l|l|}
\hline & TC(mg/dL) & HDL(mg/dL) & LDL(mg/dL) & VLDL(mg/dL) & TG(mg/dL) \\
\hline Camp2 & $3.30 \pm 0.19$ & $0.66 \pm 0.13$ & $2.28 \pm 0.12$ & $0.38 \pm 0.02$ & $0.60 \pm 0.06$ \\
\hline Ugep & $4.41 \pm 0.34$ & $1.12 \pm 0.07 *$ & $2.80 \pm 0.14^{*}$ & $0.48 \pm 0.02^{*}$ & $1.04 \pm 0.05^{*}$ \\
\hline
\end{tabular}

Values are expressed as mean \pm SEM, $n=6$

$*$ = significantly different from Camp2 at $\mathrm{p}<0.05$

\section{Comparison of serum electrolytes and non-protein nitrogen concentration of the domestic birds in camp2 and control site:}

The serum electrolytes of domestic birds presented in Table 8. The levels of $\mathrm{Na}^{+}, \mathrm{K}^{+}$, and $\mathrm{HCO}_{3}{ }^{-}$were 137.60 , 4.82 and $26.20 \mathrm{mmol} / \mathrm{L}$ respectively for Camp2 birds. The concentration of $\mathrm{Na}^{+}, \mathrm{K}^{+}$, and $\mathrm{HCO}_{3}{ }^{-}$were $140.40,4.04$ and 25.40 respectively for control birds. The difference between the concentrations of electrolytes in control and Camp2 birds did not reach statistical significance $(\mathrm{p}>0.05)$. The values of chloride $\left(\mathrm{Cl}^{-}\right)$varied from 99.80 to $100.0 \mathrm{mmol} / \mathrm{L}$. The concentration of urea and creatinine $(\mathrm{mmol} / \mathrm{L})$ of the control site (3.60 and 80.20 respectively) were significantly higher than corresponding values of 1.94 and $58.86 \mathrm{mmol} / \mathrm{L}$ for Camp2 site. Again, the mean value of $\mathrm{HCO}_{3}$ at Camp2 were non-significantly higher $(\mathrm{P}<0.05)$ with a mean value of $26.20+1.16 \mathrm{mmol} / \mathrm{l}$ compared to control site with a mean value of $25.40+0.24 \mathrm{mmol} / \mathrm{l})$. The mean value of chloride $(\mathrm{Cl})$ were non-significantly higher at Camp2 with a mean value of $100.00+3.27 \mathrm{mmol} / 1$ compared to the control site with a mean value of $99.80+0.66$. $\mathrm{mmol} / \mathrm{l}$. The mean value of the urea also shows a significant increase $(\mathrm{P}<0.05)$ at the control site with a mean value of 3.60+0.16mmol/1 Compared to the study site Camp2 with a mean value of $1.94+0.27 \mathrm{mmol} / \mathrm{l}$. Again, the mean value of Creatinine was significantly higher at control site $(\mathrm{P}<0.05)$ with mean a value of $80.28+2.04 \mathrm{mmol}$ compared with that of Creatinine at Camp2 with a mean value of $58.86+5.20 \mathrm{mmol} / \mathrm{l}$.

Table 3:- Concentrations of serum electrolytes and non-protein nitrogen in domestic birds (Gallus domestica) Analyte Concentration (mmol/L).

\begin{tabular}{|l|l|l|l|l|l|l|}
\hline & Sodium(Mmo/L) & $\mathrm{K}(\mathrm{Mmo} / \mathrm{L})$ & $\left.\mathrm{HCO}_{3}{ }^{-} \mathrm{Mmo} / \mathrm{L}\right)$ & $\mathrm{Cl}^{-}(\mathrm{Mmo} / \mathrm{L})$ & Urea(Mmo/L) & Creatinine.(Mmo/L) \\
\hline Camp2 & $137.60 \pm 3.60$ & $4.82 \pm 0.60$ & $26.20 \pm 1.16$ & $100.00 \pm 3.27$ & $1.94 \pm 0.27$ & $58.86 \pm 5.20$ \\
\hline $\begin{array}{l}\text { Control } \\
\text { site }\end{array}$ & $140.40 \pm 0.75$ & $4.04 \pm 0.16$ & $25.40 \pm 0.24$ & $99.80 \pm 0.66$ & $3.60 \pm 0.16^{*}$ & $80.28 \pm 2.04^{*}$ \\
\hline
\end{tabular}

Values are expressed as mean \pm SEM, $n=6$

$*$ = significantly different from CAMP2 at $\mathrm{p}<0.05$

\section{Discussions:-}

Man is exposed to several foreign compounds such as drugs, pollutants, food additives, cosmetics, pesticides etc. Certain unwanted compounds are produced in the large intestine by bacteria which enter the circulatory system. Human activity generates a tremendous amount of waste materials. These are discharged in various components of the environment in which they bring about undesirable changes. Heavy metals are capable of contaminating the entire environment due to their stability, they can penetrate environmental components as a result of deposition of pollution on the soil and water (Nordberg, 2005). The accumulation of heavy metal from natural and artificial sources in soil and plants could cause food safety issues and potential adverse health risks as a result of environmental pollution (Cui, 2004). Heavy metals such as $\mathrm{Zn}, \mathrm{Mn}, \mathrm{Cu}$, Co and Mo function as micronutrients for the growth of humans and animals. These are present in trace quantities, while others such as $\mathrm{As}, \mathrm{Cd}$, and $\mathrm{Cr}$ act as carcinogens (Freig, 1994). Mercury and $\mathrm{Pb}$ are associated with the development of abnormalities in children (Gillette, 1975). reported that long term intake of cadmium causes renal, prostate and ovarian cancer. Biochemical effects caused by the concentrations of heavy metals include the competition for sites with essential metabolites, replacement of essential ions, reaction with $\mathrm{SH}$ groups, damages to cell membrane and reactions with the phosphate groups (Okorokwo, 2005). Exposure to toxic heavy metals can accumulate and cause deleterious effects to some vital organs in the body. The degree of illnesses is based on acute and chronic exposure (Denkhaus, 2002). Chronic intake of heavy metals has adverse effects on human beings and animals due to the fact that there is no effective mechanism for their elimination from the body (Behemuka, 1999). Metals such as $\mathrm{Pb}, \mathrm{Hg}, \mathrm{Cd}$ and $\mathrm{Cu}$ are cumulative poisons that can cause environmental hazard (Ellen, 1990). Acute toxicity is usually from a sudden or unexpected exposure to a high level of the heavy metal. Chronic toxicity results from repeated exposure which could lead to accumulation of the toxic substance in the body. Again, this exposure may also come from contaminated food, water or even dust. (WHO, 1998). Chronic accumulation of heavy metals in the kidney and liver of human's 
causes disruption of some biochemical processes leading to cardiovascular disease, nervous and bone disease. Also, the consumption of heavy metal contaminated food can seriously deplete some essential nutrients in the body, thus causing a decrease in immunological defenses, intrauterine growth retardation, impaired psycho-social behavior, disabilities associated with malnutrition and a high prevalence of gastrointestinal cancer (Jarup, 2003). The ALT activities in the animals in Camp2 shows a significant increase compared to animals in the control sites. This increase was as a result of exposure to other contaminants in the environments. ALT is the protein metabolizing enzyme responsible for the transfer of amino group between alanine and a keto acid to form pyruvate and a new amino acid (Chattopadyaya, 1973). It is the primary enzymes responsible for the loading of ammonia from the muscles to the liver, for the urea synthesis. It is also a mitochondrial enzyme. ALT activity is usually indicative of the severity of cell injury. The results of the present study show that there was a serious injury to the animal in Camp2 that are exposed to contaminant. AST activity recorded in the present study also shows a cell injury to the hepatic cells in Camp2 study site as a result of exposure to contaminants. The aminotransferase (AST and ALT) are the most commonly use routine markers of hepatocytes injury damage with or without necrosis usually lead to the leakage of these intracellular enzymes in the blood stream. Normal level AST and ALT were between $3-15 \mu / 1$ and $4-171 \mu / 1$ respectively (Stanley, 2005). ALP activity also shows a significant increase in the study site Camp2 compared to the control site. From the deduction of the results recorded ALP play a very important roles as enzymes cofactor (Chatterjea, 2007). The enzymes, AST and ALT are both Cytoplasmic and mitochondrial enzymes involved in a wide spectrum protein metabolism, at the level of amino group transfer between glutamate and pyruvate (Champe, 2008). Total bilirubin concentrations in the animals were also compared. The results show that the total bilirubin in birds from Camp2 was significantly higher compared to that of the control site. The conjugated bilirubin and unconjugated bilirubin concentration in birds from the study site Camp2 was significantly higher compared to that in the birds from the control site. Also, both total bilirubin, conjugated and unconjugated bilirubin were within the acceptable normal values ranging from $0.3 \mathrm{mg} / \mathrm{al}-5.1-17.0 \mu \mathrm{mmol}$. A high level of bilirubin in the blood would indicate the health of the liver which could lead to jaundices. Conjugated bilirubin has to be converted to soluble bilirubin in the liver, it then goes into the bile to be stored in the gall bladder or sent to the intestines were other metabolic activity take place. Also increase in conjugated bilirubin are linked with a range of illness and coma which includes jaundice associated with hepatitis and cirrhosis anemia, luberts disease and sickle disease.The results in Table 11 show the serum electrolytes concentration of the domestic birds in Camp2 study area and the control site. From increase in the concentration of electrolyte in Camp2 compared to that of the control site. From the results sodium increase significantly in Camp2 compared to the control site. This result was within the acceptable range value of sodium concentration and the distribution for common electrolytes which value range from 134-145mg/l. However, the both results are in line with the normal range of sodium respectively sodium is one of the most important electrolytes in the body and is responsible for a number of important functions, mostly related to fluid and water regulation (Denkhaus, 2002). From the result it shows that the integrity of the kidney was maintained despites its exposure to some contaminated effluent. Sodium is one of the major electrolytes used to check the integrity and functionality of the kidney. The metabolism of sodium is regulated by aldosterone, and adrenal cortex hormone which promotes the re-absorption of sodium from kidney tubules (Beyersmanna, 2002). Sodium also maintains the body $\mathrm{pH}$ functions on transmission and contraction. Potassium $(\mathrm{K})$ concentrations were also compared, and the results show that potassium from the both study site were the same investigated. The result obtained was within the normal range value of potassium which is $3.5-50 \mathrm{mmol} / \mathrm{l}$ (Chatterjea, 2007). Potassium functions in the maintenance of acid-base equilibrium. It also functions in nerves impulse transmission which are necessary for carbohydrate and protein metabolism. It also helps in the uptake of some amino acid. Potassium maintains intracellular osmotic pressure and depolarize during contractions of the heart. The result of chloride concentration in the study site Camp2, comparing to that of the control site. The $\mathrm{Cl}^{-}$concentration in Camp2 was slightly higher than that of control site. The present result shows that the both side chloride concentration were within the acceptable range value of chloride which is $98-106 \mathrm{mmol}$. Chloride is the predominant anion that exists in the extracellular space. It maintains cellular integrity via it effects on osmotic pressure and water balance. In addition to maintaining acid-base balance excessive chloride concentration in serum is associated with congestive heart failure and the decrease renal blood-flow. Its estimate is valuable to check the accuracy for other plasma electrolytes (Gamba, 2000). Chloride is mainly transported via electro neutral cation co-transporters which allow it to always follow cation mainly $\mathrm{Na} / \mathrm{K}$ across cellular membranes cation and co-transporter are Tran's membrane proteins that include thiazide-sensitive Na-C co-transporter, loop diuretic - sensitive NaK-2C co-transporters and $\mathrm{KCl}$ co-transporters. These membrane proteins are involved in several physiological activities including trans-epithelial ion absorption and secretion, cell volume regulation, are setting intracellular $\mathrm{Cl}$ concentration below or above its electrochemical potential's equilibrium (Maji, 2005). Bicarbonate helps to evaluate and keep track of condition that effect blood bicarbonate level including liver, kidney and metabolic function. The bicarbonate result $\mathrm{HCO}_{3}{ }^{-}$shows that there was 
a significant increase in the mean concentration of $\mathrm{HCO}_{3}{ }^{-}$in Camp2 compared to the control site. This result is in line with the normal acceptable range of $\mathrm{HCO}_{3}{ }^{-}$between $23-30 \mathrm{mg}$. Bicarbonate content of serum or plasma is a significant indicator of electrolyte dispersion and anion defect. Bicarbonate measurements are used in the diagnosis and treatment of numerous potentially serious disorders associated with acid-base imbalance in the respiration and metabolic systems. The results in the both study area agree with the acceptable range stated by. Serum Creatinine of the domestic birds in Camp2 was compared with the control site. The result shows that there was a significant increase $(\mathrm{P}<0.05)$ in animals in the control sites compared to the study area of Camp2. Creatinine is a chemical waste product that produced by muscle metabolism and to extent it records the waste product from the blood. Urea concentration in the blood sample from the birds from the control site significantly increased compared to that of the study area Camp2. The value was within the acceptable range value of urea (Sunherimer, 2011). Electrolyte imbalance is commonly seen in complications most especially exposure of animals to pollutant and contaminant in the environment, that may be life threatening. Kidney is the main organ by which chemicals and their metabolites are eliminated from the body. It is the target for drug toxicity's, the many function of the kidney is to maintain the constancy of the interior environment by eliminating waste product and regulating volume electrolytes content and $\mathrm{pH}$ of the extracellular fluid in the face of varying environment demand. The serum creatinine and urea electrolyte are used to evaluate the functional capacity of the kidney. Its serum level is an index of renal function and measure the glomerular filtration rate of creatinine, Creatinine is readily filtered and does not undergo any significant tubular re-absorption. The serum increases in creatinine when the formation or excretion of urine is impaired. Urea is the major nitrogen-containing, metabolic waste product of protein catabolism in mammals. It is formed from exogenous or endogenous protein from the breakdown of cells in the lipid profile (Chatterjea, 2007). The results of the lipid profile analysis (Table 12) shows a significant difference $(\mathrm{P}<0.05)$ in lipid profile concentration of birds from the control site compared to Camp II of the study area. Lipids are heterogeneous compounds related more by their physical and chemical properties. Lipids are transported in the form of high-density lipoprotein (HDL), low density lipoprotein (LDL), very low-density lipoprotein (VLDL) and chylomicrons. Also, the levels of serum lipid parameters usually reflect the integrity and synthetic ability of the liver, as the liver is the major organic responsible for repackaging of lipids of both exogenous package by the liver. The results of the present study at the control site Ugep was within the acceptable limit and normal range for normal subject. HDL function in triacylglycerol transport by facilitating the activation of lipoprotein lipase in the transfer of triacylglycerol's between lipoprotein classes, and the removal of chylomicron remnants and VLDL enriched in triacylglycerol as well as the Apo lipoproteins. HDL includes antioxidative enzymes and phospholipids constituent are exchangeable with other lipoproteins such as LDL and VLD. Many different types of the HDL particles are generated with different metabolic roles. HDL contain many different protein constituents whose main purpose is to enable selection of cholesterol from cell esterification of cholesterol in plasma transfer of cholesterol to other lipoproteins, and the returns of cholesterol from peripheral tissues to the liver for excretion a process that is called cholesterol transfer (Gordon, 2011). There was significant increase in LDL between the two study areas LDL are the main carriers of cholesterol to the adrenal and adipose tissues were they now saves as receptors require Apo 100 that are able to take in the LDL by a similar process to that occurring in liver (Engelmann, 2008). Within these tissues, the cholesterol esters are hydrolyzed to yield and endogenous sources before they are released into circulation serum. Triacylglycerol TG show a significant difference $(\mathrm{P}<0.05)$ at the control site compared to Camp2 study area. These changes were significant, the changes were within the both study areas and are indicative of the fact that the contaminant in the environment contain metals that enhance enzymes uptake of this lipid from circulation, or even prevent lipid from getting to the liver. This might be acceptable because VLDL component are primarily responsible for transport of triacylglycerol from the liver to the other peripheral tissues (Champe, 2008). The total cholesterol levels were significantly higher in the control site at Ugep compared to that of the Camp2. Total cholesterol (TC) usually refers to as being the major component of bad lipid, and lipids are primary culprits in cardiovascular diseases and other related disease such as atherosclerosis (Stanley, 2005). Also, there was a marked increase $(\mathrm{P}<0.05)$ in the control site compared to the study site at Camp2, while there was a marked reduction in the HDL level in Camp2 domestic birds. These present results called for questioning about the integrity of the liver because the HDL in Camp2 was very low indicating the present of contaminant in the liver that could properly reduce the synthetic integrity of the liver. Hence the observed decrease in the TG and VLDL was the ability to lower the level of atherogenic predisposing factor of LDL.

\section{Conclusion:-}

The results could lead to the modification of the synthetic integrity of the cells and alteration membrane permeability leading to hepatocellular damage. Thus, it might also be as result of bioaccumulation due to long-term exposure to environmental contaminants. The report further suggests that the toxicological effect of heavy metals in the domestic birds could bring about negative impact in human health after a long time of consumption. 


\section{Conflict of interest:}

The authors declare no conflict of interest about this work.

\section{Acknowledgement:-}

This work was carried in the department of biochemistry at college of medical science, University of Calabar, Calabar. In addition, the authors would like to thank all the colleagues and staff for their contributions and valuable discussions that enriched this study.

\section{References:-}

1. Afullo, O.A. \& Odhiambo, F. (2009). The primary social waste storage gaps experienced by Nairobi household. Ethiopian Journal of Environmental Studies and Management, 3: 34-42.

2. Albores, A.F., Perez-cid, B., Gomes, E.F. \& Lopez, E.F. (2000). Comparison between sequential extraction procedures and for metal partitioning in sewage sludge. Samples Analyst 125: 1353-1357.

3. Alloway, B.J. (1996). Heavy metals in soils. London: Halsted press, John Wiley \& sons. Pp 47 - 93.

4. APHA. (2005). Standard methods for examination of water and waste water. $21^{\text {st }}$

5. Bahemuka, T.E. \& Mubofu, E.B. (1999). Heavy metals in edible green vegetables grown along the site of the sinza and Msimbazi racers in Dares Salam, Tazania. Food Chemistry, 66(1): 63-66.

6. Beyersmann, D. (2002). Effect of Carcinogenic metals on gene expression. Toxicology Letters, 127: 63-68.

7. Chakarabarti, S.K., Bai, C. \& Subramanian, K.S. (2001). DNA-protein cross links induced by mickel compounds in isolated rat hymphoeyles role of reactive oxygen species and specific amino acids. Toxicological and Applied Pharmacology, 170(3): 153-165.

8. Chalette, B.T. (1979). Environmental protection. ( $2^{\text {nd }}$ Ed). London: Kogakusha LTD, $237-302$

9. Champe, P.C. \& Harvey, R.A. (2008). Lippincott's illustrated reviews of biochemistry, ( ${ }^{\text {th }}$ Ed) Philadelphia: Raven Publishers.

10. Champe, P.C. \& Harvey, R.A. (2008). Lippincott's illustrated reviews of biochemistry, (4 ${ }^{\text {th }}$ Ed) Philadelphia: Raven Publishers

11. Chatterjea, M.N. \& Shinde, R. (2007). Textbook of medical biochemistry. $\left(7^{\text {th }}\right.$ Ed) New Delhi: Jaypee Brothers Medical Publishers. $157-172$.

12. Chatterjea, M.N. \& Shinde, R. (2007). Textbook of medical biochemistry. $\left(7^{\text {th }}\right.$ Ed) New Delhi: Jaypee Brothers Medical Publishers. $157-172$.

13. Chatterjea, M.N. \& Shinde, R. (2007). Textbook of medical biochemistry. $\left(7^{\text {th }}\right.$ Ed) New Delhi: Jaypee Brothers Medical Publishers. $157-172$

14. Chattopadyaya, S.M. (1973). Characteristics of feasibility of chrome fanning wastes. Indian Journal of Environmental Health, 15: 208.

15. Cointreau-Levine, S. (1997.). Occupational and environmental health issues of solid waste management. Special emphasis on middle and lower income countries. (Draft). World Bank report.

16. Cui, Y.V., Zhu, Y.G., Zhi, R.H., Chen, D.Y., Huang, Y.Z., Qui, Y. \& Liang, J.Z. (2004). Transfer of metals from near a smell in naming China. Environmental Internal, 30(6): 701-785.

17. Denkhaus, E. \& Salnikow, K. (2002). Nickel essentiality, toxicity and carcinogenicity. Critical Reviews in Oncology/Hematology, 42(1): 35-56.

18. Denkhaus, E. \& Salnikow, K. (2002). Nickel essentiality, toxicity and carcinogenicity. Critical Reviews in Oncology/Hematology, 42(1): 35-56.

19. Denkhaus, E. \& Salnikow, K. (2002). Nickel essentiality, toxicity and carcinogenicity. Critical Reviews in Oncology/Hematology, 42(1): 35-56.

20. Dudka, K. \& Miller, W. P. (1999). Accumulation of potential toxic elements in plants and their transfer to human food chain. Journal of Environmental Science, 34(4): 6851-708.

21. Ellen, G., Van Loon, J.W. \& Tolsma, K. (1990). Heavy metals in vegetable grown in the Netherlands and in domestic and imported fruits. Zlebensm Unters Forsch, 190: 34-39.

22. Engelmann, B. \& Wiedmann, M. K. H. (2010). Cellular phospholipid uptake: flexible paths to co-regulate the functions of intracellular lipids. Biochemical and Biophysical Acta, 1801: 609-616.

23. Freig D.I, Reid, T.M. \& Loeb, L.A. (1994). Reactive Oxygen Species in tumorgenesis. Cancer Research, 54: 1890-1894.

24. Frenkel, K. (1992). Carimogen-mediated oxidant formation and oxidative DNA damage. Pharmacology and Therapeutics, 53(1): 127-166. 
25. Gamba. (2000). Molecular, physiological and pathophysiology of electro-neutralcation-chloride co-transporters. Phys. Rev. Apr. 85(2): 423-493.

26. Gamba. (2000). Molecular, physiological and pathophysiology of electro-neutralcation-chloride co-transporters. Phys. Rev. Apr. 85(2): 423-493.

27. Gillette, J. R. (1979). Microsomes and drugs oxidation. New York: Academic Press

28. Gordon, S. M., Hofmann, S., Askew, D. S. \& Davidson, W. S. (2011). High density lipoprotein: It's not just about lipid transport anymore. Trends Endocrinology and Metabolism, 22, 9-15.

29. Jarup, L. (2003). Hazards of heavy metal contamination. British Medical Bulletin, 68(1): 167-182.

30. Karatas, M., DurSun, S., Guler, E., Ozdemir, C. \& Argun, M.E. (2006). Heavy metal accumulation in wheat plant irrigated by waste water cellulose chemistry and technology. Mutation Research, 40(7): 575-579.

31. Kimanc, N.G. (2007). Implications of the Dandora municipal Dumping site in Nairobi, Kenya. Environmental Pollution and Impacts of public health, Kenya, United Nations Environment Programme.

32. Lisk, D.J. (1998). Environmental implication of incarceration of municipal solid waste and ash disposal. The Science of the Total Environment, 74: 39-66.

33. Maji, A.K., Reddy, G.P.O., Thailand \& Walke, N.S. (2005). Characterization and classification of land form and soil over Basathi tarrain in sub-humid topic of central India. Journal of India Society of Soil Science, 53(2): 154-162.

34. Nordberg, G. F., Fowler, B. A., Nordberg, M. \& Frberg, L. (2005). Handbook on the toxicology of metals. Pp $122-126$.

35. Obono, O. (2004). Life histories of infertile women in Ugep, southern Nigeria. Union for African Population Studies. Retrieved 2006-12-30.

36. Okoronkwo, N. E., Ano, A. O. \& Onwuchekwa, E. C. (2005). Environmental health and risk assessment: a case study of the use of an abandoned municipal waste dumpsite for agricultural purpose. African Journal of Biotechnology, 4(11): 1217-1221.

37. Olorunfemi, F.B. (2009). Living with waste: Major sources of worries and concern about landfills in Lagos Metropolis, Nigeria. Ethiopian Journal of Environmental Studies and Management, 2 (2): 12-19.

38. Oluyemi, E.A., Feuyit, G., Oyekunle, J.A.O. \& Ogunfowokan, O.A. (2008). Seasonal variations in heavy metal concentration in soil and some selected crops at a landfill in Nigeria. African Journal of Environmental Science and Technology 2: 89-96.

39. Pillay, A.E., Williams, J.R., Al-lawati, M.O., Al-hadabbi, S.M.H, AL-Hamdi, M.H. \& Al-Hamdi, A. (2003). Preassessment of chromium and arsenic in date plain used as livestock feed. Environment International, 29(5): 541-545.

40. Stanley, L., Helen, K.H. \& H.H. (2005). Clinical laboratory tests, values and implications. (3rd Ed) Pennsylvania: Springhouse Press. Pp $61-98$

41. Stanley, L., Helen, K.H. \& H.H. (2005). Clinical laboratory tests, values and implications. (3rd Ed) Pennsylvania: Springhouse Press. Pp $61-98$.

42. Sunherimer, R. L. \& Graves L. (2011). Clinical laboratory chemistry. New York;Pearson Education. 150.

43. UN-Habitat. (2008). The state of African cities. A frame work as addressing urban challenges in Africa. United Nation Human Settlement Programme. Pp 23

44. United Nation Development Programme Report (UNDP). (2006). Practical action technology challenging poverty.

45. USEPA. (2002). Solid and Emergency Response. In Agency, USEPA. <http://www.epa.gov/tech. Retrieved May 2016>

46. Uwah, E.I., Ndahi, N.P., Abdularahman, F.I. \& Ogugbuaja, V.O. (2011). Heavy metal leads in spinach (Amarathus caudatus) and lettuce (Cactuca sativa) grown in Maiduguri, Nigeria. Journal of Environmental Chemistry and Ecotoxicology, 3(10): 264-271.

47. Vasudevan, D. M. \& Sreekumari, S. (2007). Textbook of biochemistry for medical students. $\left(5^{\text {th }}\right.$ Ed), New Delhi: Jaypee Brothers Medical Publishers. 85 - 117.

48. World Health Organisation (WHO). (1998). Aluminum. In: Guidelines for Drinking Water Quality, (2 ${ }^{\text {nd }}$ Ed). Geneva. Pp 33 - 34. 